that the siphuncle in Nautilus can hardly serve for such a purpose as Mr. Spath suggests. The animal would fit sufficiently tightly in the shell to prevent its falling out, even when the shell muscles were detached. ${ }^{1}$ For instance, some force is needed to pull a dead gastropod, such as a snail, from its shell even after the muscle attachment is broken.

Without discussing at any greater length the functions of the Ammonite siphuncle it may be mentioned that in the writer's opinion the suggestions of Foord ${ }^{2}$ and Dr. Henry Woodward ${ }^{3}$ are much more reasonable than those mentioned above. These writers suggest that the siphuncle was of more importance in the young animal, perhaps then serving for attachment, but that later on this function was performed by the shell muscles. It is not unlikely also that the siphuncle was of much greater importance in the early stages of Cephalopod evolution than it is in Mesozoic and recent forms. This will be more clearly recognized when an attempt is made to assign a function to the siphuncle of a Belemnite, where it is almost certainly nothing more than the remains of an organ which was probably of value in the early history of the race, and perhaps in the early development of the individual. The tendency for the secretion of the siphuncular envelope in Ammonites to lag behind shell-growth suggests that the value of the siphuncle may at least have been declining.

\title{
Angra Pequena (Lüderitzbucht) and Subaerial Denudation.
}

By R. F. RAND, M.D.

TN recent years the name of Angra Pequena, conferred by 1 Bartholomew Diaz, has been somewhat obscured by the designation Lüderitzbucht, the name given to this port during the German occupation. The latter name still holds, although a compromise, whereby the geographical area should retain the old name and the town be known as Lüderitz, seems desirable.

Angra Pequena (Lüderitzbucht) and Walfisch Bay are the only two useful harbours of the South-West African Protectorate. Apart from its harbour, the town of Luderitzbucht and the surrounding district have received much attention owing to the considerable finds of diamonds which have been made along the coast, both to the north and to the south of the port.

To the geologist the Angra Pequena area is of interest as affording

1 This would be equally true of Ammonites, in which Mr. Spath suggests that the complex lobes and saddles served as an attachment. See also Dr. W. D. Lang, "The Evolution of Ammonites": Proc. Geol. Assoc., vol. xxx, 1919, p. 63.

2 H. O. Foord, Catalogue of Fossil Cephalopods in Brit. Mus., vol. i. 1888, pp. 10-11.

H. Woodward, Pop. Sci. Review, vol. xi, 1872, p. 113. 
an admirable instance of æolian denudation. It is a desert area, a region of rock and sand. The average annual rainfall is $0.78 \mathrm{in}$. There are no running streams. Water for drinking purposes must be imported or distilled from sea-water.

The rocks are of the ancient metamorphic complex, so widespread over the Protectorate. A confused medley of granite, aplite, gneiss, and schists. There is much commingling of types as a result of injection, pressure, and earth-movement.

Overlooking the town of Lüderitzbucht there is a rocky eminence, known locally as the Diamantberg, which within an area of a square mile or so shows many types. The prevailing one is, perhaps, a biotite-schist, which in many places has been invaded to a varying degree by granite or by aplite. The difference in colour between the schistose and the granitic elements shows up the degree of admixture very clearly. In some places masses of schist are to be seen uninvaded by granite, in others masses of granite or of aplite occur without trace of schist. Here and there are large segregations of quartz. Veins and eyes of felspar are common. The rocks are exposed upon every side, for there is no vegetation that counts to mask or protect them.

Although the rainfall is so small the country is carved into hill and valley, and ravines course down the steeper slopes. The floors of the valleys are occupied by mixed sand and grit, a fluent medium, which is disposed much as water would be in a non-desert area, broadening as the valley opens out, narrowing as it closes in like a sand river-bed, which frequently provides the most convenient highway for man and beast. Heat by day and cold by night have their due effect no doubt, but it is the wind which is mainly responsible for the large quantities of rock-waste and debris which litter the surface upon all sides, and for the honeycombing the rocks have so frequently undergone.

The great destructive wind of this area blows from the S.S.W. It is a seasonal wind blowing from October until April. Years ago Andersson noted its effects upon the habits of certain birds. Perhaps only a light breeze in the morning, it rises to a gale in the afternoon, dying down again after nightfall. From time to time there are calm days. It is a wind laden with salt and with moisture where it first strikes the land; thereafter it lays the desert under tribute, and armed with grit and sand scours everything in its path.

No rock entirely withstands the attack. Effects vary. It is rather curious to see how in large boulders, say, of granite, apparently of even texture throughout, one portion of the mass may be merely dull polished and lightly scooped out, whilst another portion is deeply bitten into.

The biotite-schist shows the ravages conspicuously. The rock is pitted, riddled, and holed, with "worm-eaten", honeycombed effect. It rots array. Near to the sea, no doubt, the salt in the air, owing to its chemical reaction with the ferruginous element of the schist, adds to the destructive effect. 
The holes bored into the rock are usually more or less circular in outline at the inlet, and burrow into the rock to varying depths. The cavities worn are chambered out and frequently coalesce, giving rise to cells and caves which are sometimes large enough to shelter man.

Should granite and schist have been rolled out into even, alternate laminæ, and the constituent minerals disposed in order, the holes may be regular in size and lie in a straight line. If equidistant, as they sometimes are, they may look as though drilled by human hand. Sometimes the outlines are quadrangular, and the rows may even suggest the pigeonholes in an office desk. There may be simply smoothing and dull-polishing of such a rock, and should the layers crop out vertically they show ridge and furrow, the harder granite being in relief.

Where there has been intimate admixture of felspar and schist the more resistant felspar stands out in studs. The veins of felspar also project, but with their sides unsupported the felspar is at the mercy of its main cleavages and falls in fragments. High up upon cliff-faces one may see holes which resemble those made by martins in some hospitable sandbank.

The granite varies very much in its resistance. Sometimes it is deeply holed and cavernous; sometimes it shells away in concentric flakes; sometimes it shows good resistance and is merely dullpolished.

The segregations of quartz are, as one would suppose, very resistant. Such masses have their surfaces more or less polished and lightly scooped out into shallow depressions of varying size. All salient angles are rounded off. There is a general smoothing over. Pitting, in quartz, when it occurs, is usually small and due to the breaking down of small less-resistant inclusions. Yet the foot of a quartz slope is littered with angular fragments, owing, apparently, to the minute fissures and joints which traverse the mass.

Most of the holes one sees, whatever the nature or texture of the rock, are driven more or less horizontally inwards, after the fashion of adits, but holes are sunk downwards also. The chemical action of the wind-borne salt and moisture, and the grind of the air-driven sand and grit, sap at all vulnerable surfaces. As the holes deepen they come more and more under the swirling effect and scour of the rock-fragments, sand, and grit which they come to harbour. They may be regarded as æolian "pot-holes".

The lofty sides of the ravines and gullies have their rocks deeply honeycombed and wind-bitten. Air-currents frequently course up or down them with violence. The holes may face up or down the ravine. Perhaps there are more which face downwards. Aircurrents in broken country are so capricious and so easily deflected that there can be little rule.

One has to see the large quantities of waste littering the surface 
to realize the rapid rate at which the rock is being destroyed, and one has to experience the force of the wind adequately to estimate its driving power from its set quarter.

No one doubts that the strong S.S.W. wind has been the agent by which a natural concentration of the diamonds in the valleys of the Lüderitzbucht district has been brought about, a concentration which has made their exploitation economically possible. As the diamonds have not been shown to extend very far inland it has been thought by some that marine agency has had something to do with their occurrence. It has been pointed out that the coast is undergoing slow upheaval, and that diamonds have been found in the material of the "raised beaches" which terrace the hills in certain of the valleys of the littoral. But as to this there seems to be no reason why the enrichment should not have taken place from a landward area, and not necessarily from seawards.

It is quite likely that the S.S.W. wind may be entirely responsible for the denudation of the parent diamond-bearing rock as well as for the concentration of the diamonds after being set free. The occurrence of the diamonds near to the sea is probably due to the fact of the denuding agent being a coastal wind. This coastal wind occupies a stratum which does not reach to any considerable height into the atmosphere. As one proceeds inland the country rises fairly rapidly. In the experience of the writer it may be blowing a gale at Lüderitzbucht, while at Haalenberg, 33 miles inland by rail, and considerably less as the crow flies, the air may be nearly still. Haalenberg is 1,816 feet above sea-level. An arborescent aloe, Aloe dichotoma, common in the interior, comes down to about this neighbourhood. It does not reach the coast, it could not withstand the wind, although there are switch forms of vegetation which can bow before the wind, and lowly plants, mostly of fleshy habit, which can win their way as far down as the sea. It would seem that we have in noting the habitat of such arborescent forms as Aloe dichotoma a guide to the limitations of the coastal wind in both vertical and lateral planes, and consequently to the area the denudation of which has furnished the diamonds.

The hills lying inland between Lüderitzbucht and Kolmanskop are of metamorphic rock, and in general resemble the Diamantberg. They are not high, and one hill is very much like another. Very curiously the broad effect of the landscape in this region is suggestive of a terrain which has been swept by an ice-sheet. There are the generally rounded outlines, the hummocky effects. The resemblance must be illusory, for subaerial denudation is going on so rapidly that one judges the outlines to have been comparatively recently imposed. The directional trend of the sand-blast may be responsible for the likeness. 